\title{
Plasma LH, FSH and testosterone concentrations in adult rams which were homozygous carriers or non-carriers of the Booroola fecundity gene*
}

\author{
C. A. Price†, N. L. Hudson and K. P. McNatty \\ Wallaceville Animal Research Centre, P.O. Box 40063, Upper Hutt, New Zealand
}

\begin{abstract}
Summary. No gene-specific differences were found with respect to $\mathbf{L H}$ or testosterone pulsatile secretion (over $12 \mathrm{~h}$ ), or in 12 hourly mean FSH concentrations in adult Booroola FF and ++ rams. Also, no differences between genotypes in the $\mathrm{LH}$ response to an injection of testosterone propionate, the FSH response to an infusion of bovine follicular fluid, or the testosterone response to injections of PMSG were noted. However, during the phase of seasonal testicular development, mean testosterone pulse amplitude (over $12 \mathrm{~h}$ ) and the FSH response to $25 \mu \mathrm{g} \mathrm{GnRH}$ were higher in FF than in ++ rams $(P<0.05)$; there were also significant effects of sire $(P<0.05$ in FF genotype only) and litter size $(P<0.05)$ on testosterone pulse amplitude and GnRHstimulated FSH release, respectively. During the breeding season, mean LH, but not FSH, concentrations were higher in FF than in ++ rams, after an injection of $0.5 \mu \mathrm{g}$ GnRH; LH release was not affected by sire or litter size $(P>0.05)$.

Long-term studies revealed that the FF rams were born in significantly larger litters, they weighed significantly less than $++\operatorname{rams}(P<0.05)$, and that bodyweight was significantly correlated $(P<0.05)$ with litter size. There were no differences in testis size, and testis size was not significantly correlated with bodyweight. There was a strong tendency $(P=0.056)$ for overall mean FSH concentrations, measured weekly for 9 months, to be highest more often in FF than in ++ rams.

Collectively, these results suggest that the $F$ gene is expressed at the level of the pituitary gland in adult males, although in intact animals gene-specific differences are suppressed by the negative effect of hormones from the testis.
\end{abstract}

Keywords: Booroola rams; GnRH; LH; FSH; fecundity

\section{Introduction}

The presence of the Booroola fecundity (F) gene has various effects on the physiology and endocrinology of the pituitary-gonadal axis in female sheep; these include the maturation of ovarian follicles at small diameters, an elevation of plasma FSH concentrations, and high ovulation rates (McNatty \& Henderson, 1987; Fry et al., 1988; McNatty et al., 1989a). By contrast, strong evidence for $\mathrm{F}$ gene expression in males has not so far been produced.

There is some evidence that circulating FSH concentrations are higher in ram lambs with the F gene compared to those without (Bindon, 1984; Seck et al., 1988), and that testicular progesterone and testosterone secretion is higher in lambs carrying the $\mathrm{F}$ gene compared to non-carriers after an injection of pregnant mares' serum gonadotrophin (PMSG; Peterson et al., 1986). In adults, LH pulse frequency was higher in Booroola than in Merino rams (carriers and non-carriers of the gene,

*Reprint requests to K. P. McNatty.

†Present address: Centre de recherche en reproduction animale, Faculté de médecine vétérinaire, Université de Montréal, C.P. 5000, St Hyacinthe, Québec, Canada J2S 7C6. 
respectively; Martin et al., 1987), and Bindon et al. (1985) reported gene-specific differences in pituitary FSH content that "approach significance".

There is also evidence that does not support the expression of the F gene in males. Martin et al. (1987) reported no gene-related differences in $\mathbf{L H}$ or testosterone secretion after injection with gonadotrophin-releasing hormone $(\mathrm{GnRH})$ or human chorionic gonadotrophin, whilst Bindon $e t$ al. (1985) found no differences in mean LH and FSH concentrations between Booroola and Merino rams. Further, no gene-specific differences in testis size or in spermatogenic function have been described (Bindon et al., 1982; Walker et al., 1985).

If the $\mathrm{F}$ gene is not expressed in Booroola males, then this runs counter to the hypothesis that expression of genes controlling variation in reproductive performance is not sex-limited (Land, 1973). This hypothesis appears to hold true for the inheritance of ovulation rate and testis size in Finnish Landrace (Hanrahan \& Quirke, 1982), Romney (Knight, 1984) and non-Booroola Merino sheep (Purvis et al., 1988), and for the inheritance of altered patterns of gonadotrophin secretion associated with variation in testis size (McNeilly et al., 1988).

The aim of this experiment was to re-examine in detail several aspects of the reproductive physiology of adult Booroola Merino rams with respect to $F$ genotype.

\title{
Materials and Methods
}

\begin{abstract}
Animals
The Booroola Merino rams used in this study were homozygous carriers (FF) or non-carriers $(++; \mathrm{N}=16 /$ genotype) of the $\mathrm{F}$ gene, and, from the age of 1 year, were maintained outdoors at the Wallaceville Animal Research Centre (latitude $41^{\circ} \mathrm{S}$ ). These animals were born in 1986 at the Invermay Agricultural Research Centre (latitude $46^{\circ} \mathrm{S}$ ) as a result of controlled matings between FF ewes and rams, and between ++ ewes and rams. These dams and sires had been assigned their respective genotypes according to the criteria of Davis et al. (1982) as a result of extensive progeny and pedigree testing. The FF rams were derived from 14 ewes and 8 sires, and the ++ rams arose from 16 ewes and 3 sires.
\end{abstract}

\section{Long-term studies}

Litter size, birthweights and weaning weights were obtained from the breeding records at Invermay. From the age of 1 year, bodyweight and testis size were recorded at approximately monthly intervals for a period of 18 months. Testis size was measured with calipers, taking the length from the base of the vascular cone to the base of the testis, excluding the cauda epididymidis, and the width was taken across the widest point of the testis, correcting for scrotal skin thickness. The volume of each testis was then calculated using the formula of Walker et al. (1985), and averaged to give a mean value for each ram.

For a period of 9 months, from June to February (mid-winter to mid-summer in the southern hemisphere), blood samples were taken at weekly intervals for assay of plasma FSH concentrations.

\section{Short-term studies}

The following four treatments were imposed to assess pituitary and testicular endocrinology at 2 times of the year, namely in November (testes 'developing') and in March (testes 'active'; based on the classification of Lincoln, 1976). All animals were housed indoors during these treatments, and blood samples were withdrawn through an indwelling jugular cannula (inserted at least 1 day before sampling, in conjunction with a local anaesthetic). Within genotypes, animals were allotted to treatment groups at random.

Study 1 . The rams were bled every $10 \mathrm{~min}$ for $12 \mathrm{~h}$ to characterize pulsatile $\mathrm{LH}$ and testosterone secretion, and mean FSH concentrations.

Study 2. Immediately after the last of the 10-min samples were taken, animals received an intravenous injection of saline (controls; $\mathrm{N}=6$ /genotype), or 0.5 or $25 \mu \mathrm{g}$ GnRH (Peninsula Laboratories Inc., Belmont, CA, USA; $\mathrm{N}=5$ / genotype per dose) to assess pituitary responsiveness with respect to LH and FSH secretion, and, subsequently, the testosterone response to the LH/FSH release. After GnRH injection, the animals were blood sampled every $10 \mathrm{~min}$ for $2 \mathrm{~h}$, then every $30 \mathrm{~min}$ for a further $6 \mathrm{~h}$, for assay of LH; FSH was assayed in hourly samples, and testosterone in every other 10-min sample and each 30-min sample.

Study 3 was designed to measure the pituitary response to testicular steroid feedback, and took place 3 days after the GnRH challenge. The animals were given an intramuscular injection of 5 or $25 \mathrm{mg}(\mathrm{N}=5 /$ genotype per dose) 
testosterone propionate (Virormone: Paines \& Byrne Ltd, Greenford, UK) diluted to $1 \mathrm{ml}$ in commercial vegetable oil, and the controls were injected with $1 \mathrm{ml}$ oil alone $(\mathrm{N}=6 /$ genotype). These doses resulted in geometric mean (and $95 \%$ confidence limits) plasma concentrations of $1 \cdot 3(0 \cdot 8-1 \cdot 9), 1 \cdot 6(1 \cdot 0-2 \cdot 5)$ and $4.9(3 \cdot 1-7 \cdot 6) \mathrm{ng} / \mathrm{ml}$ testosterone, for 0 , $S$ and $25 \mathrm{mg}$ propionate, respectively; there were no differences between genotypes. Blood samples were taken immediately before and then every $30 \mathrm{~min}$ for $16 \mathrm{~h}$ after injection, and the plasma was assayed for LH and FSH content.

Study 4. The pituitary FSH response to gonadal protein feedback was examined by injecting rams with steroid-free (Henderson et al., 1986) bovine follicular fluid (bFF) as a rich source of inhibin. Rams were injected with 1 or $5 \mathrm{ml}$ bFF (s.c.; $\mathrm{N}=5$ /genotype per dose), or $1 \mathrm{ml}$ sterile saline ( $\mathrm{N}=6$ /genotype) every $8 \mathrm{~h}$ for $64 \mathrm{~h}$, and were blood sampled every $4 \mathrm{~h}$ for $72 \mathrm{~h}$, starting immediately before the first bFF injection. This study began 3 days after Study 3 .

Study 5. One further short-term study was conducted on a different group of FF $(N=8)$ and $++(N=7)$ rams, the genotypes of which were based on the same criteria as the previous group. This study was designed to measure testosterone and progesterone secretion after a bolus injection of PMSG (Folligon: Intervet, Lane Cove, NSW, Australia) in September (during seasonal testicular development). These rams were randomly assigned to receive 1000 or 3000 i.u. PMSG, and were blood-sampled daily for I week before and 3 weeks after treatment. The animals were left undisturbed for 25 days, and the experiment repeated so that those rams which previously received 1000 i.u. were then given 3000 i.u., and vice versa; the final number of animals per dose was thus 8 and 7 for the FF and ++ genotypes, respectively.

\section{Hormone assays}

$\boldsymbol{L H}$ was measured by the radioimmunoassay (RIA) described by McNatty et al. (1987a), and all samples were measured in duplicate. The minimum concentration detectable in these assays was $0.2 \mathrm{ng} / \mathrm{ml}$. Quality control samples were prepared in ram plasma that was obtained $4 \mathrm{~h}$ after an intramuscular injection of oestradiol in oil (November assays) or from hypophysectomized ewe plasma (March assays), and which contained undetectable amounts of LH. The mean intra- and inter-assay coefficients of variation were 9 and $14 \%$, respectively.

FSH concentrations were measured using a previously described RIA (McNatty et al., 1987a), and all samples were assayed in duplicate. The minimum detectable was $0 \cdot 2 \mathrm{ng} / \mathrm{ml}$. Quality control samples were prepared as for the LH assays; the mean intra- and inter-assay coefficients of variation were 6 and $9 \%$, respectively.

Progesterone and testosterone concentrations were estimated using the RIAs described by McNatty et al. (1981, 1982, respectively). Samples were extracted with freshly distilled diethyl ether, with a mean extraction efficiency of $80 \%$. The minimum detectable levels were $200 \mathrm{pg} / \mathrm{ml}$ for both steroids, and the intra- and inter-assay coefficients of variation were approximately 11 and $15 \%$.

\section{Statistics}

The data were not transformed before analysis unless the variances were significantly different between groups (Bartlett's test), in which case the data were log transformed. Untransformed data are given as arithmetic means \pm s.e.m., and transformed data are presented as geometric means and $95 \%$ confidence intervals.

The data were analysed by 1 - or 2-way ANOVA, as appropriate, to test gene-specific or gene- and dose-specific differences between groups, including as main effects sire and litter size. Differences across specific time points were analysed by Student's $t$ test. Overall mean FSH concentrations in the long-term studies were also analysed by the median test (Conover, 1971) to assess whether the frequency of higher values differed between genotypes; significance levels were established by $\chi^{2}$ tests with Yates correction.

LH and testosterone secretion was characterized in terms of pulse amplitude, pulse frequency, overall mean and smoothed mean concentrations using the Pulsar programme of Merriam \& Wachter (1982).

In the short-term studies, when pretreatment differences between groups existed, the post-treatment data were divided by the pretreatment data to obtain a 'scaled' value. These scaled values were then analysed by ANOVA.

\section{Results}

\section{Long-term studies}

There were significant differences $(P<0.05)$ in litter size, birthweight and weaning weight between FF $(3.3 \pm 0.3$ lambs, $2.5 \pm 0.2$ and $14.2 \pm 0.5 \mathrm{~kg}$, respectively) and ++ genotypes ( $1.3 \pm 0.1$ lambs, $4.4 \pm 0.1$ and $20.8 \pm 0.8 \mathrm{~kg}$, respectively). This difference was maintained into adulthood, as the FF rams weighed significantly less $(P<0.05)$ than the ++ rams at each of the 14 occasions on which they were examined. Across genotype, litter size was negatively correlated 
with birthweight $(r=-0.89 ; P<0.001)$, weaning weight $(r=-0.74 ; P<0.001)$, and with adult bodyweight $(r=-0.49 ; P<0.01 ; \mathrm{N}=32$ ). There was no significant difference between genotypes in testis volume across individual time points, and testis volume was not correlated with bodyweight $(P>0 \cdot 05)$.

The weekly geometric mean FSH concentrations and the overall 9-month mean values were not different between genotypes. When the median test was used to investigate whether the highest FSH concentrations occur more frequently in FF rams than in ++ rams, a non-significant $(P=0.056)$ result was obtained; this analysis was conducted on one annual mean for each animal.

\section{Short-term studies}

Study 1. LH and testosterone pulse data are given in Table 1 for both times of the year studied; there were no gene-specific differences for any LH secretory character. During the period of testicular growth, testosterone pulse amplitude and consequently overall mean concentrations were significantly higher in $\mathrm{FF}$ than ++ rams $(P<0.05)$; there was also a significant effect of sire $(P<0.05)$ within the FF genotype, but not the ++ genotype $(P=0.92)$, and there was no effect of litter size or bodyweight on testosterone pulse amplitude. Whilst there were no seasonal differences between overall LH mean values, smoothed mean LH concentrations were higher $(P<0.001)$ and pulses of LH and testosterone were significantly $(P<0.001)$ larger and less frequent during the phase of testicular development than they were during the active phase (for clarity, significance levels are not shown in Table 1). During the period of testicular activity, there was a significant correlation between mean LH and testosterone pulse frequency $(r=0.96, \mathrm{~N}=32$ sheep, $P<0.001$ ) and a lesser correlation between $\mathrm{LH}$ and testosterone pulse amplitude, as estimated from each individual pulse observed ( $r=0.27, n=80$ pulses, $P<0.05)$. There was no effect of genotype on these correlations.

Table 1. Pulsatile $\mathrm{LH}$ and testosterone secretion in FF and ++ $(\mathrm{N}=16 /$ genotype) rams during seasonal testicular development and activity

\begin{tabular}{|c|c|c|c|c|}
\hline & $\begin{array}{c}\text { Overall } \\
\text { mean } \\
(\mathrm{ng} / \mathrm{ml})\end{array}$ & $\begin{array}{l}\text { Smoothed } \\
\text { mean } \\
(\mathrm{ng} / \mathrm{ml})\end{array}$ & $\begin{array}{c}\text { Pulse } \\
\text { amplitude } \\
\text { (ng/ml) }\end{array}$ & $\begin{array}{c}\text { Pulse } \\
\text { frequency } \\
\text { (per } 12 \mathrm{~h} \text { ) }\end{array}$ \\
\hline \multicolumn{5}{|l|}{ Testis developing } \\
\hline $\begin{array}{ll}\mathrm{LH} & \mathrm{FF} \\
& ++\end{array}$ & $\begin{array}{l}0.5 \pm 0.1 \\
0.4 \pm 0.1\end{array}$ & $\begin{array}{l}0.4 \pm 0.07 \\
0.3 \pm 0.04\end{array}$ & $\begin{array}{l}2.9 \pm 0.4 \\
2.5 \pm 0.3\end{array}$ & $\begin{array}{l}1.9 \pm 0.2 \\
1.5 \pm 0.2\end{array}$ \\
\hline \multicolumn{5}{|l|}{ Testosterone } \\
\hline $\begin{array}{r}\text { FF } \\
++\end{array}$ & $\begin{array}{l}3 \cdot 5 \pm 0 \cdot 4^{\mathrm{a}} \\
2 \cdot 3 \pm 0 \cdot 2^{\mathrm{b}}\end{array}$ & $\begin{array}{l}1.4 \pm 0.3 \\
0.8 \pm 0.2\end{array}$ & $\begin{array}{l}7 \cdot 4 \pm 0 \cdot 7^{\mathrm{c}} \\
5 \cdot 4 \pm 0.4^{\mathrm{d}}\end{array}$ & $\begin{array}{l}1.9 \pm 0.2 \\
1.5 \pm 0.2\end{array}$ \\
\hline \multicolumn{5}{|l|}{ Testis active } \\
\hline $\begin{array}{ll}\text { LH } & \text { FF } \\
& ++\end{array}$ & $\begin{array}{l}0.4 \pm 0.1 \\
0.4 \pm 0.1\end{array}$ & $\begin{array}{l}0.2 \pm 0.02 \\
0.2 \pm 0.02\end{array}$ & $\begin{array}{l}1.6 \pm 0.2 \\
1.5 \pm 0.2\end{array}$ & $\begin{array}{l}2 \cdot 5 \pm 0.3 \\
2 \cdot 8 \pm 0.3\end{array}$ \\
\hline \multicolumn{5}{|l|}{ Testosterone } \\
\hline $\begin{array}{l}\text { FF } \\
++\end{array}$ & $\begin{array}{l}1.3 \pm 0.2 \\
1.4 \pm 0.1\end{array}$ & $\begin{array}{l}0.3 \pm 0.05 \\
0.4 \pm 0.05\end{array}$ & $\begin{array}{l}2.8 \pm 0.4 \\
3.8 \pm 0.5\end{array}$ & $\begin{array}{l}3.9 \pm 0.4 \\
3.4 \pm 0.4\end{array}$ \\
\hline
\end{tabular}

Values are arithmetic means \pm s.e.m.

Values within columns with different superscripts are significantly different $(P<0.05)$.

There were no gene-specific differences in mean FSH secretion during the 12-h sampling periods (data not shown); pulses of FSH were not evident in our assay system.

Study 2. The effects of a bolus injection of GnRH on pituitary LH and FSH release, and subsequent testosterone concentrations, are given in Table 2. There was a clear effect of GnRH 
dose on LH secretion $(P<0.001)$ at both times of the year, but not on FSH or testosterone secretion. Since the FSH and testosterone responses were less well-defined than the LH responses, broader post-treatment means were taken for analysis. FF rams secreted significantly $(P<0.05)$ more $\mathrm{LH}$ than did ++ rams in response to $0.5 \mu \mathrm{g} \mathrm{GnRH}$ when the testes were active, and there were no significant effects of sire or litter size on this response; no other gene-specific effects on $\mathrm{LH}$ or testosterone secretion were noted. In contrast to LH, FSH secretion was not consistently stimulated by $\mathrm{GnRH}$, particularly in the $0.5 \mu \mathrm{g}$ dose groups. During the period of testicular development there was a significantly higher $(P<0.05)$ mean FSH response to $25 \mu \mathrm{g} \mathrm{GnRH}$ in FF than in ++ rams, and a significant effect of litter size $(P<0.05)$ but no effect of sire $(P>0.05)$.

Table 2. Scaled pituitary and testicular hormone responses to two doses of GnRH in.FF and $++(\mathrm{N}=16 /$ genotype $)$ rams during seasonal testicular development and activity

\begin{tabular}{|c|c|c|c|c|}
\hline $\begin{array}{l}\text { GnRH } \\
\text { dose }\end{array}$ & Genotype & $\begin{array}{l}\text { Scaled LH } \\
\text { peak values* }\end{array}$ & $\begin{array}{l}\text { Scaled mean } \\
\text { FSH over } 4 h^{*}\end{array}$ & $\begin{array}{c}\text { Scaled mean } \\
\text { testosterone } \\
\text { over } 1.5 \mathrm{~h} \\
\text { (mean } \pm \text { s.e.m.) }\end{array}$ \\
\hline $\begin{array}{r}\text { Testis de } \\
0.5 \mu \mathrm{g}\end{array}$ & ing $\begin{array}{r}\text { FF } \\
++\end{array}$ & $\begin{array}{rr}8 \cdot 8 & (4 \cdot 3-18 \cdot 3) \\
13 \cdot 3 & (6 \cdot 4-27 \cdot 5)\end{array}$ & $\begin{array}{l}0.8(0.6-1 \cdot 1) \\
0.8(0.6-1.2)\end{array}$ & $\begin{array}{r}6.2 \pm 3.3 \\
11.8 \pm 2.5\end{array}$ \\
\hline $25 \mu \mathrm{g}$ & $\begin{array}{l}\text { FF } \\
++\end{array}$ & $\begin{array}{l}54 \cdot 7(26 \cdot 4-113 \cdot 7) \\
79 \cdot 8(38 \cdot 4-165 \cdot 7)\end{array}$ & $\begin{array}{l}1.5(1 \cdot 1-2 \cdot 0)^{\mathrm{a}} \\
0.8(0 \cdot 6-1 \cdot 0)^{\mathrm{b}}\end{array}$ & $\begin{array}{r}7 \cdot 4 \pm 3 \cdot 2 \\
11.7 \pm 3 \cdot 7\end{array}$ \\
\hline $\begin{array}{r}\text { Testis act } \\
0.5 \mu \mathrm{g}\end{array}$ & $\begin{array}{l}\text { FF } \\
++\end{array}$ & $\begin{array}{l}25 \cdot 4(13 \cdot 1-49 \cdot 3)^{\mathrm{c}} \\
11.9(6 \cdot 1-23 \cdot 1)^{d}\end{array}$ & $\begin{array}{l}0.8(0 \cdot 5-1 \cdot 3) \\
1 \cdot 2(0 \cdot 7-1 \cdot 9)\end{array}$ & $\begin{array}{r}12 \cdot 6 \pm 3 \cdot 2 \\
8.3 \pm 4.5\end{array}$ \\
\hline $25 \mu \mathrm{g}$ & $\begin{array}{l}\text { FF } \\
++\end{array}$ & $\begin{array}{l}46 \cdot 3(23 \cdot 9-89 \cdot 6) \\
60 \cdot 4(31 \cdot 1-116 \cdot 9)\end{array}$ & $\begin{array}{l}1 \cdot 5(0 \cdot 9-2 \cdot 5) \\
2 \cdot 0(1 \cdot 2-3 \cdot 2)\end{array}$ & $\begin{array}{l}18.8 \pm 6.5 \\
11.8 \pm 3.4\end{array}$ \\
\hline
\end{tabular}

*Geometric means and $95 \%$ confidence intervals.

a,b.c.dSignificant difference $(P<0.05)$ between genotypes.

Study 3. The mean LH concentrations measured 8-16 h after injection of 0,5 or $25 \mathrm{mg}$ testosterone propionate were $0.6 \pm 0 \cdot 1,0.4 \pm 0.1$ and $0.4 \pm 0 \cdot 1 \mathrm{ng} / \mathrm{ml}$ for the FF rams, and $0.8 \pm 0 \cdot 1,0.5 \pm 0 \cdot 1$ and $0.4 \pm 0 \cdot 1 \mathrm{ng} / \mathrm{ml}$, respectively, for the ++ rams, during testicular development. When the testes were in the 'active' phase, the LH concentrations were respectively, $0.3 \pm 0 \cdot 1,0.3 \pm 0.1$ and $0.2 \pm 0.1 \mathrm{ng} / \mathrm{ml}$, for each dose for the FF rams, and $0.4 \pm 0.1,0.3 \pm 0.1$ and $0.2 \pm 0.1 \mathrm{ng} / \mathrm{ml}$ for the ++ rams. Irrespective of season, there was a significant $(P<0.05)$ effect of dose, but not of genotype $(P>0.05)$ on mean LH concentrations. There was no effect of this treatment on FSH concentrations $(P>0.05)$.

Study 4. The geometric mean (and $95 \%$ confidence intervals) FSH concentrations during Hours 24-72 after starting the infusion of 0,1 or $5 \mathrm{ml} \mathrm{bFF}$ were $0 \cdot 3(0 \cdot 2-0 \cdot 4), 0 \cdot 2(0 \cdot 1-0.3)$ and $0.1(0.1-0.2) \mathrm{ng} / \mathrm{ml}$ for the FF rams, and $0.3(0.2-0.4), 0.2(0.1-0.2)$ and $0.1(0.1-0.2) \mathrm{ng} / \mathrm{ml}$, respectively, for the ++ rams, during the period of testicular activity. The effect of dose was significant $(P<0.05)$, but the effect of genotype was not $(P>0.05)$. During the period of testicular development, most FSH values were below the limit of detection of the assay, and so analyses were not performed on these data.

Study 5. Plasma testosterone concentrations started to rise on the day after injection of PMSG, peaked over Days 6-8 after injection, and then declined to pre-treatment levels by Day 15 in the 1000 i.u. dose group and approached pre-treatment levels by the end of the sampling period (Day 21 ) in the 3000 i.u. dose group. The mean ( \pm s.e.m.) scaled peak (Days $6-8$ ) values after 1000 i.u. PMSG were $4.8 \pm 0.5$ and $5 \cdot 1 \pm 0.7$ for FF and ++ rams, respectively, and after 3000 i.u. PMSG were $15.9 \pm 4.0$ and $10.0 \pm 1.6$ for FF and ++ rams, respectively. The effect of dose was 
significant $(P<0.05)$ for each genotype, and there were no gene-specific differences at either dose studied. The doses of PMSG used in this study had no effects upon plasma progesterone concentrations, which were close to or below the limit of detection of the assay (data not shown).

\section{Discussion}

These findings are not inconsistent with the hypothesis that F-gene expression is associated with elevated gonadotrophin secretion in the Booroola ram, although the evidence is not as strong as that for the ewe.

Long-term sampling (weekly for 9 months) revealed a strong tendency $(P=0.056)$ for FF rams to have the highest plasma FSH concentrations more often than the ++ rams, although there were no gene-specific differences across individual time points, or in short-term FSH concentrations (hourly samples over $12 \mathrm{~h}$ ). These data are in agreement with those for the ewe, in which gene-specific differences in mean FSH concentrations at specific time points are not consistently observed (McNatty et al., 1987a, 1989b), whereas long-term mean concentrations and the frequency with which the highest values occurred, were consistently higher in FF than in ++ ewes (McNatty et al., 1987a, 1989a). These data could explain why the 3-h sampling period of Bindon $e t$ al. (1985) failed to detect a difference between Booroola and control Merino rams. It is also clear that FSH concentrations are very much lower in rams than in ewes and so any subtle differences will be more difficult to detect. For instance, the difference in luteal-phase mean FSH concentrations between FF and ++ ewes reported by McNatty et al. (1987a) is $1 \mathrm{ng} / \mathrm{ml}$, and since mean FSH concentrations in rams are approximately $20 \%$ of those in ewes (see McNatty et al., 1987a; this study), one might then predict a gene-specific difference in rams of $0.2 \mathrm{ng} / \mathrm{ml}$; such a difference would be extremely difficult to detect statistically.

The short-term sampling in the present study permitted analysis of the pulsatile secretion of LH. There was a significant effect of season on the magnitude and frequency of $\mathrm{LH}$ pulses, in agreement with previous studies (Lincoln, 1978). However, no gene-specific differences were found for any secretory component. These data are at variance with those of Martin et al. (1987), who indicated that LH (and subsequent testosterone) pulses occurred more often in Booroola than in Merino rams, and were often detected together in groups. No such 'grouping' of LH pulses was evident in the present data. The discrepancy between these two studies may have been caused by non F-gene specific strain differences as Martin et al. (1987) were comparing Booroola and nonBooroola Merino strains, whereas all the present rams were of the same Booroola strain, differing only in the possession of the $F$ gene. The current results also differ from those for the ewe, for which LH pulse amplitude was reported to be higher in FF than in ++ intact and ovariectomized ewes (McNatty et al., 1987a, 1989a). The reason for this difference is unclear, but may be in part due to sex differences in hypothalamo-pituitary function.

The present study has shown some gene-related differences in GnRH-induced pituitary function. During seasonal testicular development, FF rams secreted significantly more FSH, but not $\mathrm{LH}$, than did ++ rams, after an injection of $25 \mu \mathrm{g} \mathrm{GnRH}$; the lower dose of GnRH had no effect upon FSH secretion. During the period of testicular activity, the plasma concentrations of $\mathrm{LH}$, but not FSH were elevated in the FF rams compared to the ++ rams, this time after $0.5 \mu \mathrm{g}$ $\mathrm{GnRH}$; the higher dose maximally stimulated both genotypes equally. These data therefore suggest that the pituitary glands were more sensitive to $\mathrm{GnRH}$ in FF than in ++ rams, but that their maximal secretory capacity, at least in the case of $\mathrm{LH}$, was not different between genotypes. These data do not support those of Martin et al. (1987), who showed no significant differences between Booroola and Merino rams after GnRH treatment, nor do they reconcile with the data for the ewe, for which it was suggested that FF ewes secrete less gonadotrophin than ++ ewes in response to GnRH (McNatty et al., 1987a). Again, these discrepancies may be ascribed, in part, to possible strain and sex variation. The discrepancy between the present ram data and the previous ewe study 
(McNatty et al., 1987a) is unlikely to be caused by differences in experimental design, as the source of the GnRH and the dose range used were identical, and the sampling protocols were very similar.

Gene-specific differences in pituitary sensitivity did not extend to the negative feedback influence of the testis. There was a significant suppressive effect of testosterone propionate on mean LH, but not FSH concentrations, as shown by previous studies in rams (Galloway \& Pelletier, 1975), and infusion of bFF significantly suppressed mean FSH concentrations presumably through the actions of inhibin (de Jong, 1988), but there were no gene effects in either of these two experiments. Whilst McNatty et al. (1989b) showed that there were no gonadotrophin differences between ovariectomized FF and ++ ewes treated with oestradiol, progesterone or bFF, the present data should be interpreted with caution; a bolus injection of testosterone propionate is not a physiological challenge, and the bFF reduced low FSH concentrations to levels which approached or reached the minimum detectable limit of the assay. Confirmation of these results must await studies of castrated rams.

There were no gene-specific differences in plasma steroid concentrations in previous reports for ewes (McNatty \& Henderson, 1987) and rams (Martin et al., 1987), but in the present study during testicular development FF rams displayed a significantly higher testosterone pulse amplitude than did ++ rams. This may reflect an increased sensitivity, to stimulation by $\mathbf{L H}$, of the developing but not the developed testis. Comparable information on steroid release in Booroola ewes during the transition from anoestrus to the breeding season is not available.

The difference in bodyweight between the genotypes can probably be accounted for by the higher litter size in the FF compared to the ++ genotype, which in turn resulted in smaller lambs and ultimately smaller adults. Bodyweight differences in FF vs ++ adult ewes (McNatty et al., 1987a), and in F $+v s++$ ewe lambs at 3 months of age (McNatty et al., 1987b) were not significant. There were no gene-specific differences in testis size at each monthly assessment, in agreement with earlier reports (Bindon et al., 1982; Walker et al., 1985), although this is not consistent with other selection lines in sheep (Hanrahan \& Quirke, 1982; Purvis et al., 1988). There is an explanation which may account for the present bodyweight and testis size data: McNeilly et al. (1986) suggested that sexual maturity occurred earlier in Finn Dorset rams selected for large testis diameter as lambs, compared to those selected for low juvenile testis size, which led to a decreased adult bodyweight but no difference in adult testis size. This mechanism cannot be discounted in the Booroola, as it has been suggested that FF lambs mature earlier than do ++ rams, based on developmental changes in preputial adhesion score and the proportion of rams that exhibited mounting behaviour at 5 months of age (Walker et al., 1985). Studies on the development of the testis in ram lambs of the New Zealand Booroola genotype have yet to be done.

Some of the gene-related differences in hormone secretion in this study were confounded by effects of sire (GnRH-stimulated FSH release) or litter size (testosterone pulse amplitude). An effect of sire on mean FSH concentrations in ram lambs has been reported (Seck et al., 1988), and it is not known if this is related to or independent of the $F$ gene. However, the differences in GnRH-stimulated LH secretion were gene-specific, and not significantly affected by sire or litter size.

In conclusion, the studies reported here offer support for the hypothesis that expression of the $F$ gene is not sex-limited. Specifically, rams with the $F$ gene secrete more gonadotrophin in response to GnRH and are likely to have higher mean plasma FSH concentrations more often than rams without the gene. It is also suggested that potential gene-specific differences are obscured by hormonal negative feedback from the testis; studies of castrated Booroola rams are in progress.

We thank the staff of the Invermay Agricultural Research Centre for provision of the animals and details of their reproductive history; Mike Fisher, Louise Shaw and Lisa Condell for the LH and FSH assays; Kathy Ball, Richard Bailey, Derek Heath, Doug Jensen, Stan Lun and Peter 
Smith for assistance with animal handling and blood sampling; Dr K. M. Henderson for assistance during the overnight bleeds; and the National Hormone \& Pituitary Program and the NIADDK for radioimmunoassay reagents. C.A.P. was supported by a New Zealand NRAC Postdoctoral Fellowship.

\section{References}

Bindon, B.M. (1984) Reproductive biology of the Booroola Merino sheep. Austr. J. biol. Sci. 37, 163-189.

Bindon, B.M., Piper, L.R. \& Evans, R. (1982) Reproductive biology of the Booroola Merino. In The Booroola Merino. Proceedings of a Workshop, pp. 21-33. CSIRO, Melbourne.

Bindon, B.M., Piper, L.R., Cummins, L.J., O'Shea, T., Hillard, M.A., Findlay, J.K. \& Robertson, D.M. (1985) Reproductive endocrinology of prolific sheep: studies of the Booroola Merino. In Genetics of Reproduction in Sheep, pp. 217-235. Eds R. B. Land \& D. W. Robinson. Butterworths, London.

Conover, W.J. (1971) Practical Nonparametric Statistics, 2nd edn, pp. 171-178. John Wiley \& Sons, New York.

Davis, G.H., Montgomery, G.W., Allison, A.J., Kelly, R.W. \& Bray, A.R. (1982) Segregation of a major gene influencing fecundity in progeny of the Booroola sheep in New Zealand. N.Z. J. agric. Res. 25, 51 5-529.

Fry, R.C., Clarke, I.J., Cummins, J.T., Bindon, B.M., Piper, L.R. \& Cahill, L.P. (1988) Induction of ovulation in chronically hypophysectomized Booroola ewes. J. Reprod. Fert. 82, 711-715.

Galloway, D.B. \& Pelletier, J. (1975) Luteinizing hormone release in entire and castrated rams following injection of synthetic luteinizing hormone releasing hormone, and effects of testosterone propionate pre-treatment. J. Endocr. 64, 7-16.

Hanrahan, J.P. \& Quirke, J.F. (1982) Selection on ovulation rate in sheep aided by the use of superovulation and egg transfer. In Proc. Wld. Congr. Sheep and Beef Cattle Breeding, pp. 329-335. Eds R. A. Barton \& W. C. Smith. Dunmore Press Ltd, Palmerston North.

Henderson, K.M., Prisk, M.D., Hudson, N., Ball, K., McNatty, K.P., Lun, S., Heath, D., Kieboom, L.E. \& McDiarmid, J. (1986) Use of bovine follicular fluid to increase ovulation rate or prevent ovulation in sheep. J. Reprod. Fert. 76, 623-635.

de Jong, F.H. (1988) Inhibin. Physiol. Rev. 68, 555-607.

Knight, T.W. (1984) Testicular growth and size in rams from flocks of different reproductive potential. N.Z. J. agric. Res. 27, 179-189.

Land, R.B. (1973) The expression of female sex-limited characters in the male. Nature, Lond. 241, 208-209.

Lincoln, G.A. (1976) Seasonal variation in the episodic secretion of luteinizing hormone and testosterone in the ram. J. Endocr. 69, 213-226.

Lincoln, G.A. (1978) The temporal relationship between plasma levels of FSH and LH in the ram. J. Reprod. Fert. 53, 31-37.

Martin, G.B., Sutherland, S.R.D. \& Lindsay, D.R. (1987) Effects of nutritional supplements on testicular size and the secretion of $\mathrm{LH}$ and testosterone in Merino and Booroola rams. Anim. Reprod. Sci. 12, 267-281.
McNatty, K.P. \& Henderson, K.M. (1987) Gonadotrophins, fecundity genes and ovarian follicular function. J. Steroid Biochem. 27, 365-373.

McNatty, K.P., Gibb, M., Dobson, C., Thurley, D.C. \& Findlay, K. (1981) Changes in the concentrations of gonadotrophic and steroidal hormones in the antral fluid of ovarian follicles throughout the oestrous cycle of the sheep. Aust. J. biol. Sci. 34, 67-80.

McNatty, K.P., Gibb, M., Dobson, C., Ball, K., Coster, J., Heath, D. \& Thurley, D.C. (1982) Preovulatory follicular development in sheep treated with PMSG and/or prostaglandin. J. Reprod. Fert. 65, 111-123.

McNatty, K.P., Hudson, N., Henderson, K.M., Gibb, M., Morrison, L., Ball, K. \& Smith, P. (1987a) Differences in gonadotrophin concentrations and pituitary responsiveness to $\mathrm{GnRH}$ between Booroola ewes which were homozygous $(\mathrm{FF})$, heterozygous $(\mathrm{F}+)$ and non-carriers $(++)$ of a major gene influencing their ovulation rate. J. Reprod. Fert. 80, 577-588.

McNatty, K.P., Lun, S., Heath, D.A. \& O'Keeffe, L.E. (1987b) Ovarian activity in Booroola lambs with and without a fecundity gene. J. Reprod. Fert. 79, $57-66$.

McNatty, K.P., Fisher, M., Collins, F., Hudson, N.L., Heath, D.A., Ball, K. \& Henderson, K.M. (1989a) Differences in the plasma concentrations of FSH and LH in ovariectomized Booroola FF and ++ ewes. J. Reprod. Fert. 85, 705-713.

McNatty, K.P., Hudson, N.L., Collins, F., Fisher, M., Heath, D.A. \& Henderson, K.M. (1989b) Effects of oestradiol-17 $\beta$, progesterone or bovine follicular fluid on the plasma concentrations of FSH and LH in ovariectomized Booroola ewes which were homozygous carriers or non-carriers of a fecundity gene. $J$. Reprod. Fert. 87, 573-585.

McNeilly, J.R., Fordyce, M., Land, R.B., Lee, G.J. \& Webb, R. (1986) Endocrine differences in rams after genetic selection for testis size. J. Reprod. Fert. 76, $131-140$.

McNeilly, J.R., Fordyce, M., Land, R.B., Martin, G.B., Springbett, A.J. \& Webb, R. (1988) Changes in the feedback control of gonadotrophin secretion in ewes from lines selected for testis size in the ram lamb. $J$. Reprod. Fert. 84, 213-221.

Merriam, G.R. \& Wachter, K.W. (1982) Algorithms for the study of episodic hormone secretion. Am. J. Physiol. 243, E310-E318.

Peterson, A.J., Shanley, R.R. \& Moore, R.W. (1986) Pituitary-gonadal responses in ram lambs with or without the Booroola $F$ gene after gonadotrophin injection. Proc. Endocr. Soc. Austr. 29, abstract E10.

Purvis, I.W., Piper, L.R., Edey, T.N. \& Kilgour, R.J. (1988) The genetic relationship between ovulation rate and testicular diameter in a random-breeding Merino flock. Livestock Prodn Sci. 18, 35-54. 
Seck, M., Hochereau-de-Reviers, M-T. \& Boomarov, 0. (1988) Comparaisons des teneurs plasmatiques en hormone gonadotrope FSH, durant les trois premiers mois de la vie, chez des agneaux mâles, porteurs ou non du gène $\ll \mathrm{F} \gg$ de prolificité. $C$. $r$. hebd. Séanc. Acad. Sci., Paris 307, Série 3, 433-437.
Walker, S.K., Ponzoni, R.W., Walkley, J.R.W. \& Morbey, A.S.C. (1985) The effect of the F gene on male reproductive traits in Booroola $\times$ South Australian Merino rams. Anim. Reprod. Sci. 9, 137-144.

Received 10 May 1990 